\title{
12. CARBON ISOTOPE RATIO OF TOTAL INORGANIC CARBON IN PORE WATERS ASSOCIATED WITH DIAGENESIS OF ORGANIC MATERIAL AT SITE 808, NANKAI TROUGH ${ }^{1}$
}

\author{
Toshitaka Gamo, ${ }^{2}$ Miriam Kastner, ${ }^{3}$ Ulrich Berner, ${ }^{4}$ and Joris Gieskes ${ }^{3}$
}

\begin{abstract}
The $\delta^{13} \mathrm{C}$ values of total inorganic carbon $\left(\Sigma \mathrm{CO}_{2}\right)$ were measured for interstitial waters extracted from the turbidite and hemipelagic sediments of the Nankai Trough accretionary prism during ODPLeg 131. At $3.0 \mathrm{mbsf}$ in the bacterial sulfate reduction zone, a significant low $\delta^{13} \mathrm{C}$ of $-29.8 \%$ (PDB) was found, suggesting oxidation of upward-migrated methane from the zone below. At $6.0 \mathrm{mbsf}$, below the sulfate reduction zone, the $\delta^{13} \mathrm{C}$ value increases abruptly to a maximum value of $+12.0 \%$, reflecting an enrichment of ${ }^{13} \mathrm{C}$ in residual $\Sigma \mathrm{CO}_{2}$ from the bacterial reduction of some $\Sigma \mathrm{CO}_{2}$ to ${ }^{12} \mathrm{C}$-enriched $\mathrm{CH}_{4}$. Below 80 mbsf, the ${ }^{13} \mathrm{C}$ values decrease almost linearly with depth to $\sim-20 \%$ at $1000 \mathrm{mbsf}$, indicating that the fraction of $\Sigma \mathrm{CO}_{2}$ derived from thermal degradation of organic material increases gradually with increasing in-situ temperature.
\end{abstract}

\section{INTRODUCTION}

That $\delta^{13} \mathrm{C}$ of total inorganic carbon $\left(\Sigma \mathrm{CO}_{2}\right)$ in interstitial waters is a sensitive indicator of the degradation processes of organic matter has been demonstrated for various marine environments (e.g., Nissenbaum et al., 1972; Claypool and Kaplan, 1974; Irwin et al., 1977; Grossman, 1984; McCorkle et al., 1985; Berner et al., in press). In this study we measure variations of the carbon isotope ratio of interstitial waters, and interpret their geochemical implications with respect to organic matter diagenesis in rapidly deposited sediments of the Nankai Trough accretionary prism south of Japan.

$\Sigma \mathrm{CO}_{2}$ and its carbon isotope composition $\left(\delta^{13} \mathrm{C}\right)$ in interstitial waters are controlled by anaerobic bacterial (sulfate reduction, fermentation, and methane generation) as well as thermocatalytic degradation processes of organic matter. As shown for example by Claypool and Kaplan (1974), at shallow burial depths just below the aerobic respiration zone, bacterial sulfate reduction (reaction 1) is the dominant process for decomposing organic matter $\left(\mathrm{CH}_{2} \mathrm{O}\right)$ :

$$
2 \mathrm{CH}_{2} \mathrm{O}+\mathrm{SO}_{4}{ }^{2-} \rightarrow 2 \mathrm{CO}_{2}+\mathrm{S}^{2-}+2 \mathrm{H}_{2} \mathrm{O}
$$

After $\mathrm{SO}_{4}$ is completely consumed from interstitial waters, bacterial methane generation $\left(\mathrm{CO}_{2}\right.$ reduction) is considered to occur as shown in reaction 3 , where fermentation-derived $\mathrm{CO}_{2}$ (reaction 2) as well as the sulfate reduction $\mathrm{CO}_{2}$ (reaction 1) is reduced to $\mathrm{CH}_{4}$ (Whiticar et al., 1986).

$$
\begin{gathered}
2 \mathrm{CH}_{2} \mathrm{O}+2 \mathrm{H}_{2} \mathrm{O} \rightarrow 2 \mathrm{CO}_{2}+4 \mathrm{H}_{2} \\
\mathrm{CO}_{2}+4 \mathrm{H}_{2} \rightarrow \mathrm{CH}_{4}+2 \mathrm{H}_{2} \mathrm{O} .
\end{gathered}
$$

At high in-situ temperatures of greater than $50^{\circ} \mathrm{C}$, thermocatalytic decarboxylation of organic acid functional groups also occurs:

$$
\mathrm{R}-\mathrm{CO}_{2} \mathrm{H} \rightarrow \mathrm{R}-\mathrm{H}+\mathrm{CO}_{2} \text {. }
$$

The carbon isotopic ratio $\left({ }^{13} \mathrm{C} /{ }^{12} \mathrm{C}\right)$ of the produced and remaining $\Sigma \mathrm{CO}_{2}$ varies among the processes. Little carbon isotopic fractionation occurs between organic material and the $\mathrm{CO}_{2}$ in reactions 1,2 , and 4

\footnotetext{
'Hill, I.A., Taira, A., Firth, J.V., et al., 1993. Proc. ODP, Sci. Results, 131: College Station, TX (Ocean Drilling Program).

${ }^{2}$ Ocean Research Institute, University of Tokyo, Nakano, Tokyo 164, Japan.

${ }^{3}$ Scripps Institution of Oceanography, University of California, San Diego, La Jolla, CA 92093 , U.S.A.

${ }^{4}$ Federal Institute for Geosciences and Natural Resources, Stilleweg 2,3000 Hannover 51. Federal Republic of Germany.
}

(e.g., Claypool and Kaplan, 1974; Irwin et al., 1977), while reaction 3 causes a significant enrichment in ${ }^{13} \mathrm{C}$ in the residual $\Sigma \mathrm{CO}_{2}$, because ${ }^{12} \mathrm{CO}_{2}$ is removed at a rate about $7 \%$ faster than ${ }^{13} \mathrm{CO}_{2}$ during methane formation (Rosenfeld and Silverman, 1959). This is also documented through the high fractionation factors of 1.055-1.09 reported by Whiticar et al. (1986).

During the ODP Leg 131 cruise (March 30 to June 2, 1990), sediment core samples were taken from the following three holes at Site 808: Hole $808 \mathrm{~A}, 32^{\circ} 21.116^{\prime} \mathrm{N}, 134^{\circ} 56.666^{\prime} \mathrm{E}$, depth $=4676.0$ mbsf; Hole $808 \mathrm{~B}, 32^{\circ} 21.085^{\prime} \mathrm{N}, 134^{\circ} 56.613^{\prime} \mathrm{E}$, depth $=4674.2 \mathrm{mbsf}$; and Hole $808 \mathrm{C}, 32^{\circ} 21.170^{\prime} \mathrm{N}, 134^{\circ} 56.657^{\prime} \mathrm{E}$, depth $=4674.6 \mathrm{~m}$, in the western Nankai Trough accretionary prism (see Fig. 1), as reported by Taira, Hill, Firth, et al. (1991). The total organic carbon, whose content varies within the range of $0.1 \mathrm{wt} \%$ and $0.75 \mathrm{wt} . \%$, shows an apparent decrease with depth (Taira, Hill, Firth et al., 1991). The depth profiles of $\delta^{13} \mathrm{C}$ of dissolved $\Sigma \mathrm{CO}_{2}$, of $\mathrm{CH}_{4}$ and of kerogen as well as of $\mathrm{SO}_{4}{ }^{2-}$ and titration alkalinity concentrations in the squeezed interstitial waters (or in the sediments), enabled us to trace each organic matter diagenetic process mentioned above.

\section{EXPERIMENTAL METHODS}

Interstitial waters were retrieved on board the ship by using stainless steel or titanium squeezers (Manheim and Sayles, 1974) immediately after the core samples were brought on deck. Samples of 1 to $5 \mathrm{~mL}$ were sealed for carbon isotope ratio analysis in glass ampules in vacuum and stored in darkness.

After the cruise, the $\Sigma \mathrm{CO}_{2}$ in each sample was completely extracted by acidifying and bubbling an aliquot of the sample in $\mathrm{CO}_{2}$ free helium flow or by acidifying the whole sample by breaking the glass ampule in an evacuated ball mill made of Pyrex glass (Kita et al., 1982). There was no systematic difference between the results of the two methods. Water vapor in the evolved $\mathrm{CO}_{2}$ gas was removed by condensing it at dry-ice temperature, and the $\mathrm{CO}_{2}$ was collected in a trap cooled by liquid nitrogen. Carbon isotope analysis was carried out at the Ocean Research Institute, University of Tokyo, with a Finnigan MAT 250 mass spectrometer modified for small sample analysis. Isotope results are expressed as per mil values relative to the PDB standard:

$$
\delta^{13} \mathrm{C}=\left\{\left(R_{\text {sample }} / R_{\text {standard }}\right)-1\right\} \times 1,000,
$$

where $R={ }^{13} \mathrm{C} /{ }^{12} \mathrm{C}$. The $\delta^{13} \mathrm{C}$ values were calibrated by using the NBS-16 and NBS-17 CO $\mathrm{CO}_{2}$ standards (Coplen et al., 1983). The accuracy of $\delta^{13} \mathrm{C}$ measurements is estimated to be $\pm 0.1 \%$. 


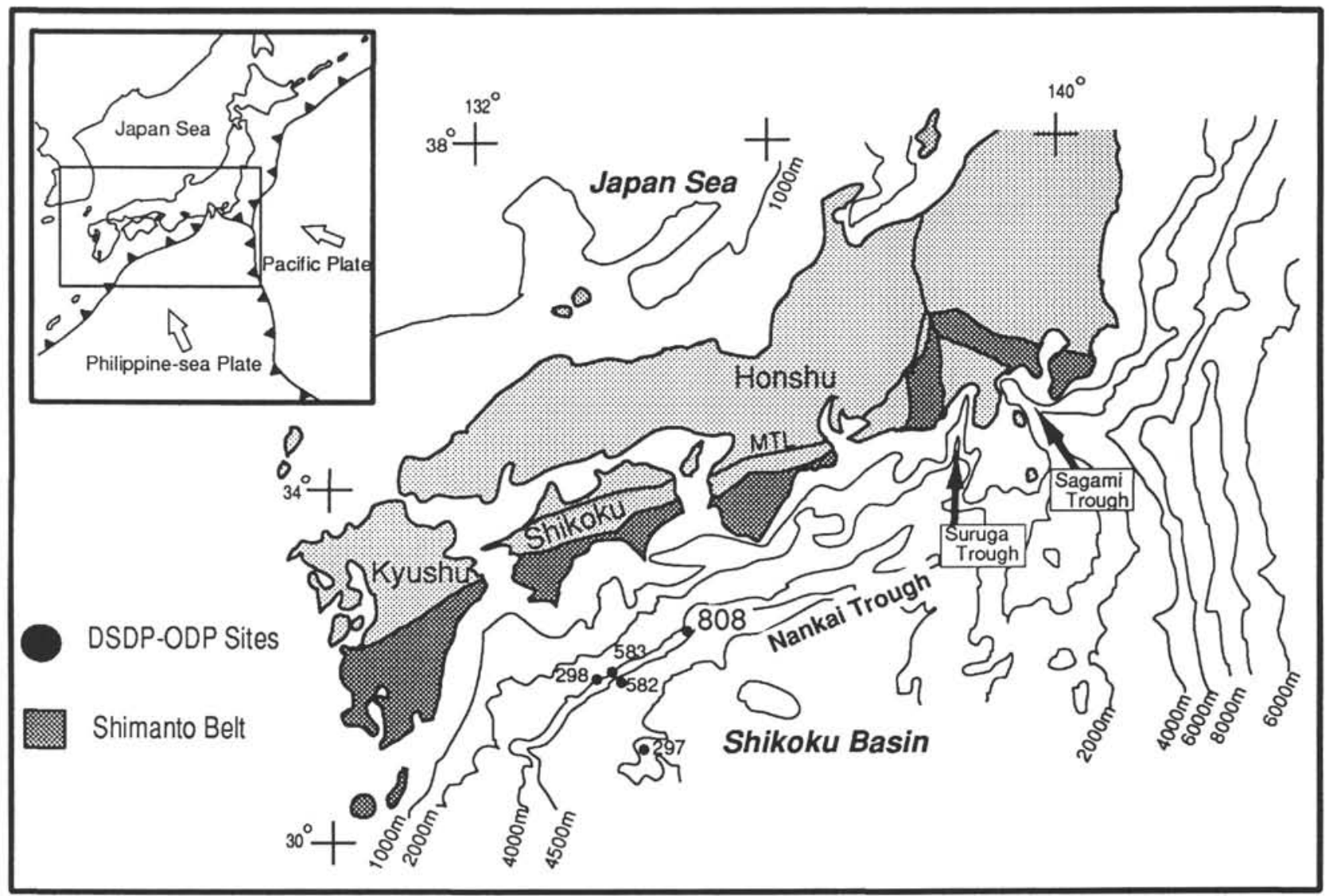

Figure 1. A bathymetric map showing the locations of Site 808 and nearby DSDP sites along the Nankai Trough as well as of the Shikoku Basin and the Shimanto Belt, an ancient accretionary prism (Taira, Hill, Firth, et al., 1991).

In addition to the interstitial water samples, nearby bottom seawater collected $\sim 20 \mathrm{~m}$ above the seafloor at $\left(32^{\circ} 23^{\prime} \mathrm{N}, 135^{\circ} 01^{\prime} \mathrm{E}\right)$ by the Tansei Maru (Ocean Research Institute, University of Tokyo) was analyzed using the same procedure for reference.

The diagenetic carbonate samples were also analyzed for $\delta^{13} \mathrm{C}$ values at the Scripps Institution of Oceanography following the procedure of McCrea (1950). The $\delta^{13} \mathrm{C}$ measurements for $\mathrm{CH}_{4}$ and organic matter (kerogen) in the sediment samples were performed at the Federal Institute for Geosciences and Natural Resources (Berner and Faber, this volume; Berner and Koch, this volume).

\section{RESULTS AND DISCUSSION}

Figure 2 shows a general lithostratigraphy for Site 808 (Taira, Hill, Firth, et al., 1991). The sediments at Site 808 are roughly classified into two layers: trench turbidites (0-557 mbsf, Units I-IIc) and the Shikoku Basin hemipelagic sediments (619-1243 mbsf, Unit IVaIVb). The rate of sediment accumulation for the upper layer is extremely rapid $(787-1381 \mathrm{~m} / \mathrm{m} . \mathrm{y}$.), while that for the lower layer is relatively slow (46-107 m/m.y) (Taira, Hill, Firth, et al., 1991). Pore-water chemistry of Site 808 is summarized in detail by Gieskes et al. (this volume).

Table 1 lists the results of $\delta^{13} \mathrm{C}$ measurements for $\Sigma \mathrm{CO}_{2}$ together with the data of titration alkalinity and $\mathrm{SO}_{4}{ }^{2-}$ that were measured on board the ship (Taira, Hill, Firth et al., 1991). The values reported as $0 \mathrm{mbsf}$ are those of the bottom seawater sample mentioned above.

Figure 3 shows the vertical profiles of $\delta^{13} \mathrm{C}\left(\Sigma \mathrm{CO}_{2}\right), \mathrm{SO}_{4}{ }^{2-}$, and titration alkalinity over the depth interval of 0 to 30 mbsf. The $\mathrm{SO}_{4}{ }^{2-}$ concentration decreases steeply from $28.9 \mathrm{mM}$ to zero at 6.0 mbsf, which means that the sulfate reduction zone is restricted to a very narrow zone, of the uppermost $6.0 \mathrm{~m}$ of the section. Indeed, only in the first two samples (Nos. 131-808A-1H-3 and -1H-4) was the distinct smell of hydrogen sulfide noticed (Taira, Hill, Firth et al., 1991). Titration alkalinity increases abruptly from $2.4 \mathrm{mM}$ to 39.9 $\mathrm{mM}$ between 0 and $6.0 \mathrm{mbsf}$, reflecting the production of $\Sigma \mathrm{CO}_{2}$ due to decomposition of organic matter by bacterial sulfate reduction.

In the sulfate reduction zone, $\delta^{13} \mathrm{C}\left(\Sigma \mathrm{CO}_{2}\right)$ values abruptly decrease from the bottom seawater value of $+0.7 \%$ to $-29.8 \%$ at $3.0 \mathrm{mbsf}$. It is worth noting that this single measured value is significantly lower than the value of the organic matter of $-24 \%$ (Berner and Koch, this volume). Because the $\mathrm{CO}_{2}$ production by sulfate reduction (reaction 1) causes little carbon isotope fractionation between the $\mathrm{CO}_{2}$ and organic matter as described earlier, there must be another carbon source with a lower ${ }^{13} \mathrm{C}$ value than marine organic matter. The methane generation process below the $\mathrm{SO}_{4}$ reduction zone that produces $\mathrm{CH}_{4}$ with a much lower ${ }^{13} \mathrm{C}$ value than that of organic matter, is an obvious internal light carbon source. Therefore, $\mathrm{CH}_{4}$ may diffuse upward into the sulfate reduction zone, where a portion of it is being oxidized to $\mathrm{CO}_{2}$ (Whiticar and Faber, 1986). The overall reaction is:

$$
\mathrm{CH}_{4}+\mathrm{SO}_{4}{ }^{2-} \rightarrow \mathrm{CO}_{2}+\mathrm{S}^{2-}+2 \mathrm{H}_{2} \mathrm{O}
$$

In fact, a minor amount of $\mathrm{CH}_{4}(40 \mathrm{ng} / \mathrm{g})$ was detected in the sediment sample at 2.95 mbsf (Berner and Faber, this volume). The unusually ${ }^{13} \mathrm{C}$-poor $\Sigma \mathrm{CO}_{2}\left(\delta^{13} \mathrm{C}=-35.2 \%\right.$ ) was also observed at 3 mbsf at Site 582 in the western Nankai Trough (see Fig. 1) during DSDP Leg 87 (Claypool et al., 1986).

At $6.0 \mathrm{mbsf}$, below the $\mathrm{SO}_{4}$ reduction zone, the $\delta^{13} \mathrm{C}\left(\Sigma \mathrm{CO}_{2}\right)$ increases rapidly to $12.0 \%$, and keeps a constant value of $10 \%$ - $11 \%$ 


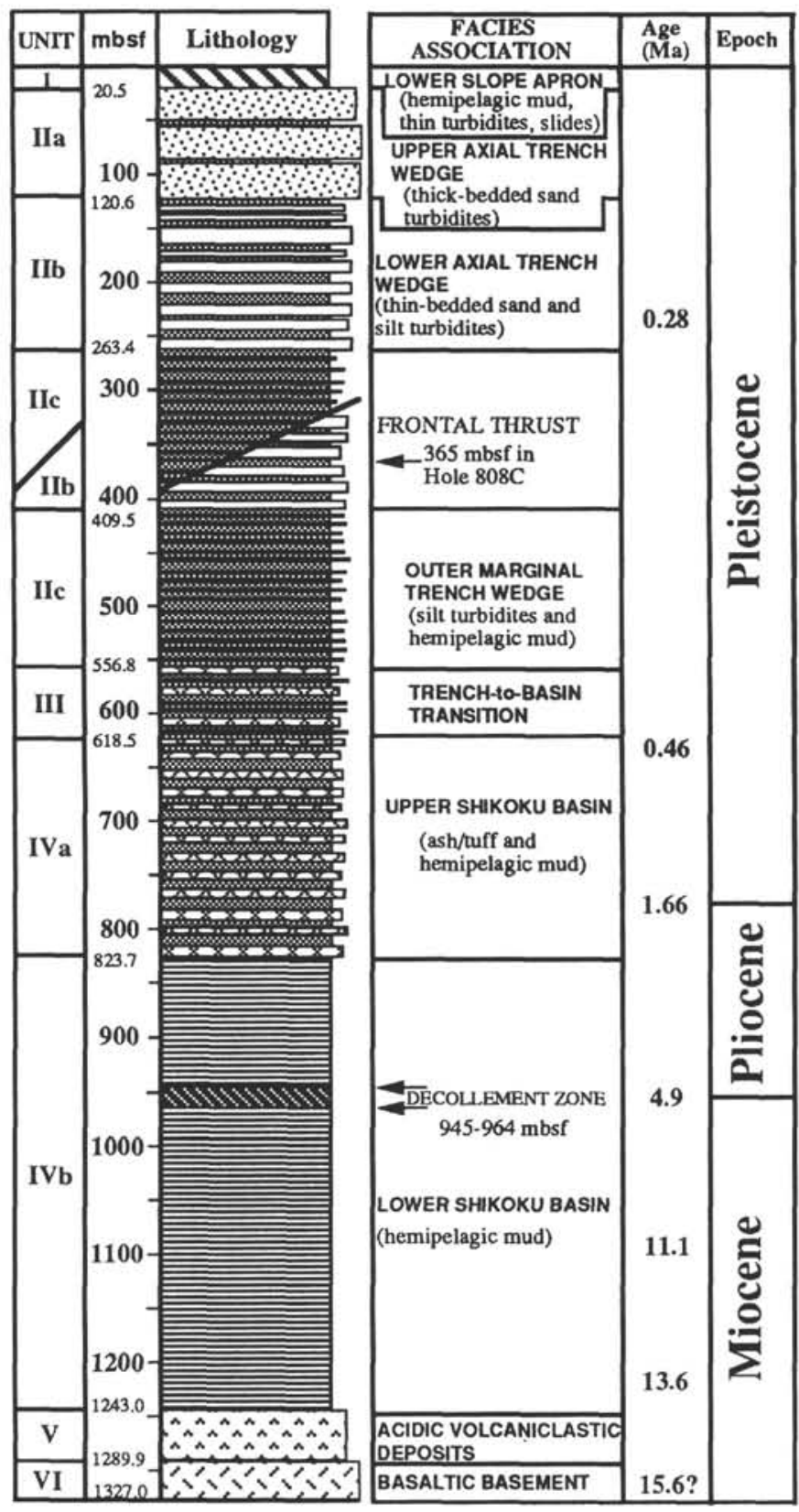

Figure 2. Summary of lithostratigraphy and age for Site 808 (Taira, Hill, Firth, et al., 1991).

between 6.0 and $80.8 \mathrm{mbsf}$ as shown in Table 1 and Figure 3. The rapid increase of $\delta^{13} \mathrm{C}\left(\Sigma \mathrm{CO}_{2}\right)$ clearly indicates the initiation of methane generation by bacterial reduction of $\mathrm{CO}_{2}$ (reaction 3) that causes a large carbon isotope fractionation between $\mathrm{CO}_{2}$ and $\mathrm{CH}_{4}$ as described earlier. Indeed, the measured $\delta^{13} \mathrm{C}$ values of $\mathrm{CH}_{4}$ are expectedly low, $-71.7 \%$ at 19.02 mbsf and $-65.4 \%$ at $55.25 \mathrm{mbsf}$ (Berner and Faber, this volume). Such positive $\delta^{13} \mathrm{C}\left(\Sigma \mathrm{CO}_{2}\right)$ values due to $\mathrm{CH}_{4}$ generation were also observed at the DSDP Sites 582 and 583 (Claypool et al., 1986). As this ${ }^{13} \mathrm{C}$-enriched $\Sigma \mathrm{CO}_{2}$ is thought to migrate upward into the sulfate reduction zone along with the $\mathrm{CH}_{4}$, even more $\mathrm{CH}_{4}$ oxidation is implied to maintain the low $\delta^{13} \mathrm{C}\left(\mathrm{\Sigma CO}_{2}\right)$ value in the sulfate reduction zone.

Below $80.8 \mathrm{mbsf}$, the $\delta^{13} \mathrm{C}\left(\Sigma \mathrm{CO}_{2}\right)$ decreases gradually and almost linearly with depth as shown in Figure 4 , where $\delta^{13} \mathrm{C}$ values for authigenic pure calcite recovered from the sediments at 910 and 1063 mbsf are also plotted as alternatives for the interstitial water data,
Table 1. Interstitial water $\delta^{13} \mathrm{C}\left(\mathrm{\Sigma CO}_{2}\right)$, titration alkalinity (TA), and $\mathrm{SO}_{4}{ }^{2-}$ concentrations, Site 808.

\begin{tabular}{lrrrrrrr}
\hline Hole & Core & Sec. & Int. (cm) & $\begin{array}{r}\text { Depth } \\
\text { (mbsf) }\end{array}$ & $\delta^{13} \mathrm{C}(\%)$ & $\mathrm{TA}(\mathrm{mM})$ & $\mathrm{SO}_{4}(\mathrm{mM})$ \\
\hline & & & & 0.0 & 0.7 & 2.40 & 28.9 \\
808A & $1 \mathrm{H}$ & 3 & $0-10$ & 3.0 & -29.8 & 24.06 & 10.6 \\
$808 \mathrm{~A}$ & $1 \mathrm{H}$ & 4 & $140-150$ & 6.0 & 12.0 & 39.92 & 0.5 \\
$808 \mathrm{~A}$ & $2 \mathrm{H}$ & 3 & $0-10$ & 9.3 & 9.2 & 47.72 & 0.2 \\
$808 \mathrm{~A}$ & $2 \mathrm{H}$ & 5 & $140-150$ & 13.8 & 10.0 & 48.11 & 0.0 \\
$808 \mathrm{~A}$ & $3 \mathrm{H}$ & 3 & $0-10$ & 18.8 & 11.2 & 46.55 & 0.0 \\
$808 \mathrm{~A}$ & $4 \mathrm{H}$ & 1 & $135-150$ & 26.8 & 11.0 & 44.96 & 0.2 \\
$808 \mathrm{~A}$ & $7 \mathrm{H}$ & 4 & $135-150$ & 59.7 & 10.8 & 55.14 & 0.0 \\
$808 \mathrm{~A}$ & $8 \mathrm{H}$ & 1 & $135-150$ & 64.7 & 10.8 & 54.67 & 0.3 \\
$808 \mathrm{~A}$ & $10 \mathrm{H}$ & 3 & $0-15$ & 80.8 & 11.0 & 51.72 & 0.0 \\
$808 \mathrm{~A}$ & $13 \mathrm{H}$ & 2 & $122-137$ & 109.0 & 8.9 & 40.63 & 0.1 \\
$808 \mathrm{~B}$ & $5 \mathrm{X}$ & 1 & $88-103$ & 151.0 & 7.5 & 24.97 & 0.0 \\
$808 \mathrm{~B}$ & $10 \mathrm{X}$ & 4 & $130-150$ & 203.0 & 4.7 & 17.62 & 0.8 \\
$808 \mathrm{~B}$ & $11 \mathrm{X}$ & 2 & $130-150$ & 209.7 & 5.2 & 17.60 & 0.8 \\
$808 \mathrm{~B}$ & $13 \mathrm{X}$ & 1 & $125-145$ & 227.0 & 4.4 & 16.15 & 0.8 \\
$808 \mathrm{~B}$ & $17 \mathrm{X}$ & 2 & $130-145$ & 266.5 & 3.1 & 13.98 & 1.1 \\
$808 \mathrm{~B}$ & $23 \mathrm{X}$ & $\mathrm{CC}$ & $5-10$ & 317.0 & 2.8 & & 0.5 \\
$808 \mathrm{C}$ & $1 \mathrm{R}$ & 1 & $133-150$ & 299.9 & 1.3 & 16.04 & 1.3 \\
$808 \mathrm{C}$ & $6 \mathrm{R}$ & 3 & $108-118$ & 350.7 & 0.9 & 15.08 & 1.6 \\
$808 \mathrm{C}$ & $10 \mathrm{R}$ & 2 & $130-150$ & 388.1 & 0.7 & & 2.7 \\
$808 \mathrm{C}$ & $12 \mathrm{R}$ & 1 & $130-150$ & 406.0 & 0.5 & 16.42 & 3.6 \\
$808 \mathrm{C}$ & $13 \mathrm{R}$ & 2 & $135-150$ & 417.2 & 0.6 & 16.88 & 2.5 \\
$808 \mathrm{C}$ & $18 \mathrm{R}$ & 3 & $130-150$ & 466.8 & -1.5 & 13.14 & 1.0 \\
$808 \mathrm{C}$ & $20 \mathrm{R}$ & 4 & $132-150$ & 487.6 & -4.1 & & 1.7 \\
$808 \mathrm{C}$ & $21 \mathrm{R}$ & 1 & $120-144$ & 492.6 & -5.3 & 13.27 & 0.7 \\
$808 \mathrm{C}$ & $29 \mathrm{R}$ & 6 & $125-150$ & 577.5 & -5.8 & 4.87 & 0.9 \\
$808 \mathrm{C}$ & $34 \mathrm{R}$ & 2 & $125-150$ & 619.4 & -9.2 & 5.61 & 0.6 \\
$808 \mathrm{C}$ & $35 \mathrm{R}$ & 4 & $132-150$ & 632.1 & -8.0 & 5.02 & 0.5 \\
$808 \mathrm{C}$ & $46 \mathrm{R}$ & 2 & $125-150$ & 734.4 & -9.9 & & 1.5 \\
$808 \mathrm{C}$ & $60 \mathrm{R}$ & 4 & $116-150$ & 872.5 & -14.0 & & 2.8 \\
\hline & & & & & & &
\end{tabular}

because little carbon isotope fractionation occurs between $\Sigma \mathrm{CO}_{2}$ and authigenic calcium carbonate.

The decrease of $\delta^{13} \mathrm{C}\left(\Sigma \mathrm{CO}_{2}\right)$ with depth suggests that the addition of isotopically light $\mathrm{CO}_{2}$ by fermentation (reaction 2) occurs at a faster rate than $\mathrm{CO}_{2}$ removal by $\mathrm{CH}_{4}$ generation (reaction 3 ). Also, below $\sim 400 \mathrm{mbsf}$, the importance of thermal degradation of organic acid functional groups (reaction 4), which also produces isotopically light $\mathrm{CO}_{2}$, increases with depth. The temperature profile estimated from the heat flow of $126-129 \mathrm{~mW} / \mathrm{m}^{2}$ (Taira, Hill, Firth et al., 1991) indicates that the in-situ temperature below $400 \mathrm{mbsf}\left(50^{\circ} \mathrm{C}\right)$ is high enough to support thermal decomposition of organic matter (Hunt, 1979; Tissot and Welte, 1984). The existence of thermogenic hydrocarbons has been evidenced by the appearance of $\mathrm{C}_{2} \mathrm{H}_{6}, \mathrm{C}_{3} \mathrm{H}_{8}$, and $\mathrm{C}_{4} \mathrm{H}_{10}$ at depths greater than $340-390$ mbsf as well as the decrease of $\mathrm{CH}_{4} / \mathrm{C}_{2} \mathrm{H}_{6+}$ ratio with depth (Taira, Hill, Firth, et al., 1991). Higher content of thermal hydrocarbons at greater depth is also confirmed by the relationship between $\delta^{13} \mathrm{C}\left(\mathrm{CH}_{4}\right)$ and $\mathrm{C}_{1} /\left(\mathrm{C}_{2}+\mathrm{C}_{3}\right)$ ratio (Berner and Faber, this volume).

The $\delta^{13} \mathrm{C}\left(\Sigma_{2} \mathrm{CO}_{2}\right)$ at $\sim 1000$ mbsf is approximately $-20 \%$, which is very close to the value of the organic matter of $-24 \%$ (Berner and Koch, this volume) as shown in Figure 4 . As bacterial activity should be extremely limited by a high temperature of $\sim 90^{\circ} \mathrm{C}$ at this depth (Taira, Hill, Firth et al., 1991), bacterial processes (reactions 2 and 3) are unlikely. Most of the $\Sigma \mathrm{CO}_{2}$ at $\sim 1000 \mathrm{mbsf}$ is therefore thought to be derived thermogenically.

\section{CONCLUDING REMARKS}

The origin of $\Sigma \mathrm{CO}_{2}$ in the interstitial waters from the Nankai Trough accretionary sediments was deduced from its $\delta^{13} \mathrm{C}$ value and interstitial water chemistry. $\Sigma \mathrm{CO}_{2}$ within the bacterial $\mathrm{SO}_{4}$-reducing zone in the uppermost $6 \mathrm{~m}$ of the sediment column is shown to be a mixture of $\Sigma \mathrm{CO}_{2}$ formed by in-situ oxidation of sedimentary organic matter in this zone and of $\mathrm{CH}_{4}$ that has migrated from the zone below. Just below the $\mathrm{SO}_{4}$-reducing zone, bacterial fermentation accompa- 


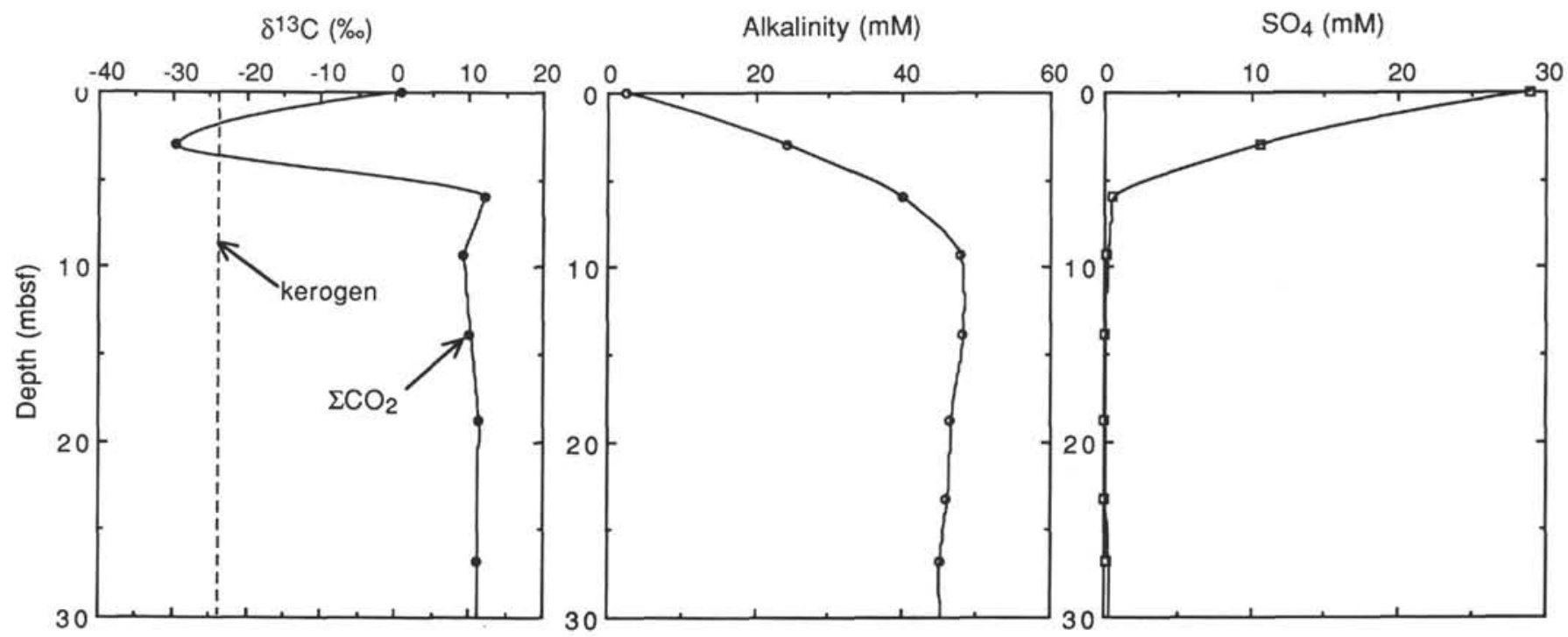

Figure 3. Depth profiles of $\delta^{13} \mathrm{C}\left(\Sigma \mathrm{CO}_{2}\right)$, titration alkalinity, and $\mathrm{SO}_{4}{ }^{2-}$ concentrations, between 0 and $30 \mathrm{mbsf}$, Site 808 . Kerogen $\delta^{13} \mathrm{C}$ data is marked by a dashed line (Berner and Koch, this volume).

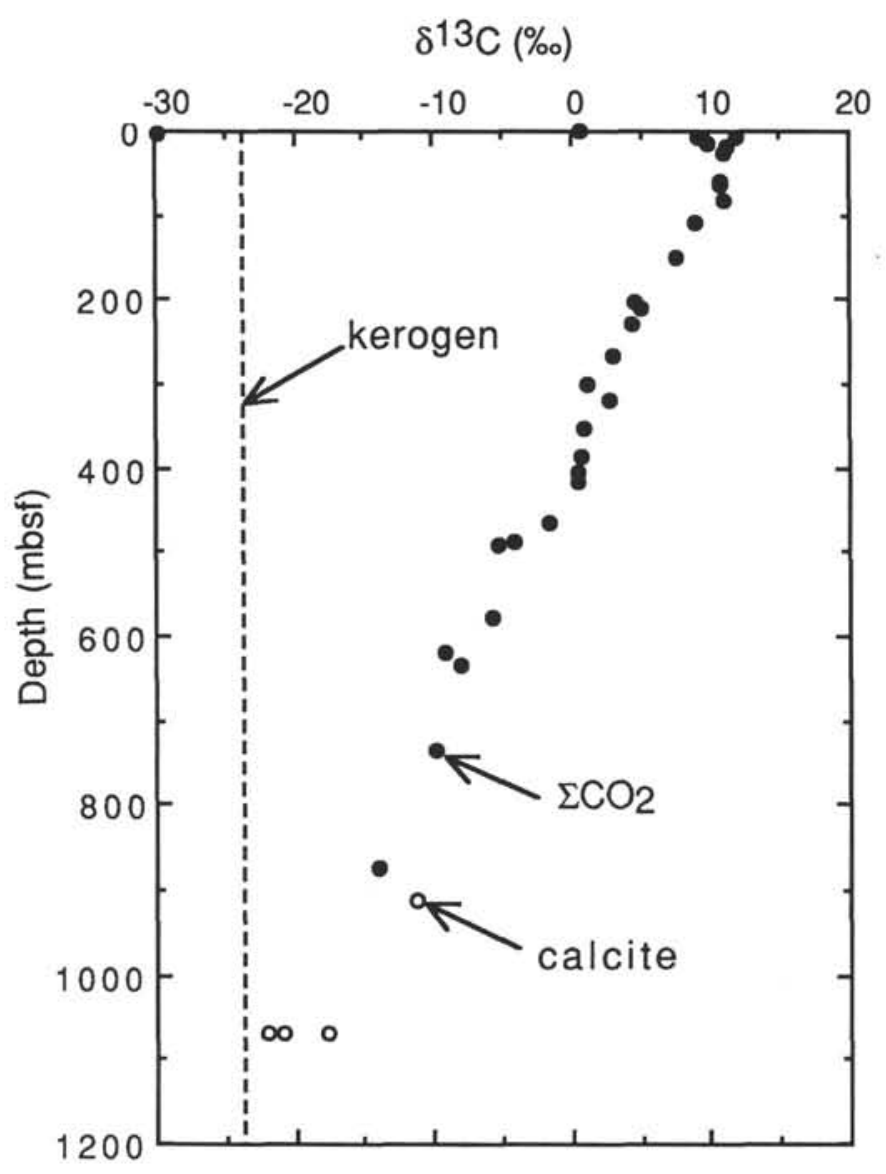

Figure 4. Vertical profile of $\delta^{13} \mathrm{C}\left(\Sigma \mathrm{CO}_{2}\right)$ over the depth interval of $0-1200$ mbsf at Site 808. Solid circles are the interstitial water data, and open circles are the authigenic calcite data. The $\delta^{13} \mathrm{C}$ values of the organic matter are indicated by a dashed line (Berner and Koch, this volume). nied by methane generation plays a dominant role in producing $\Sigma \mathrm{CO}_{2}$ with a high $\delta^{13} \mathrm{C}$ value of $12 \%$. With increasing depth and higher temperature, the fraction of thermogenic $\Sigma \mathrm{CO}_{2}$ increases as seen from the monotonous decrease of the $\delta^{13} \mathrm{C}\left(\Sigma \mathrm{CO}_{2}\right)$ values with depth as well as from the evolution of light hydrocarbons.

\section{ACKNOWLEDGMENT}

The authors thank the shipboard scientific party as well as the captain and crew on board JOIDES Resolution during the Leg 131 cruise. Thanks are also due the shipboard crew of Tansei Maru for bottom-water sampling. I. Kita and $\mathrm{H}$. Masuda kindly offered the glass ball mill for the $\Sigma \mathrm{CO}_{2}$ extraction. Comments by R.J. Behl, G.E. Claypool, and P. Vrolijk were useful for improving the initial manuscript. This study was partially supported by the grant-in-aid for Scientific Research on Priority Areas "Ocean Fluxes-Their Role in the Geosphere and the Biosphere" (No. 03248103) from the Ministry of Education, Science and Culture of Japan (to T. G.), by JOI/U.S. Science support grant (to M. K.), and by the Deutsche Forschungs Gemeinshaft (to U. B.).

\section{REFERENCES}

Berner, U., von Breymann, M.T., Faber, E., and Bertrand, P., in press. Gas geochemistry of ODP Sites 767 and 768, Celebes and Sulu Seas. Proc. Symp. on Bacterial Gases, Milano. Paris (Edition Technip.).

Claypool, G.E., and Kaplan, I.R., 1974. The origin and distribution of methane in marine sediments. In Kaplan, I.R. (Ed.), Natural Gases in Marine Sediments: New York (Plenum), 99-139.

Claypool, G.E., Vuletich, A.K., and Kvenvolden, K.A., 1986. Isotopic composition of interstitial fluids in sediment of the Nankai Trough, Deep Sea Drilling Project Leg 87. In Kagami, H., Karig, D.E., Coulbour, W.T., et al., Init. Repts. DSDP, 87: Washington (U.S. Govt. Printing Office), 857-860.

Coplen, T.B., Kendall, C., and Hopple, J., 1983. Comparison of stable isotope reference samples. Nature, 302:236-238.

Grossman, E.L., 1984. Carbon isotopic fractionation in live benthic foraminifera-comparison with inorganic precipitate studies. Geochim. Cosmochim. Acta, 48:1505-1512.

Hunt, J.M., 1979. Petroleum Geochemistry and Geology: San Francisco (W.H. Freeman). 
Irwin, H., Curtis, C., and Coleman, M., 1977. Isotopic evidence for source of diagenetic carbonates formed during burial of organic-rich sediments. Nature, 269:209-213.

Kita, I., Matsuo, S., and Wakita, H., 1982. $\mathrm{H}_{2}$ generation by reaction between $\mathrm{H}_{2} \mathrm{O}$ and crushed rock: an experimental study on $\mathrm{H}_{2}$ degassing from the active fault zone. J. Geophys. Res., 87:10789-10795.

McCrea, J.M., 1950. The isotopic chemistry of carbonates and a paleotemperature scale. J. Chem. Phys., 18:849-857.

Manheim, F.T., and Sayles, F.L., 1974. Composition and origin of interstitial waters of marine sediments, based on deep sea drill cores. In Goldberg, E.D. (Ed.), The Sea (Vol. 5): New York (Wiley-Interscience), 527-568.

McCorkle, D.C., Emerson, S.R., and Quay, P.D., 1985. Stable carbon isotopes in marine porewaters. Earth Planet. Sci. Lett., 74:13-26.

Nissenbaum, A., Presley, B.J., and Kaplan, I.R., 1972. Early diagenesis in a reducing fjord, Saanich Inlet, British Columbia, I. Chemical and isotopic changes in major components of interstitial water. Geochim. Cosmochim. Acta, 36:1007-1027.
Rosenfeld, W.D., and Silverman, S.R., 1959. Carbon isotope fractionation in bacterial production of methane. Science, 130:1658-1659.

Taira, A., Hill, I., Firth, J., et al., 1991. Proc. ODP, Init. Repts., 131: College Station, TX (Ocean Drilling Program).

Tissot, B.P., and Welte, D.H., 1984. Petroleum Formation and Occurrence (2nd ed.): Heidelberg (Springer-Verlag).

Whiticar, M.J., and Faber, E., 1986. Methane oxidation in sediment and water column environments-isotope evidence. Org. Geochem., 10:759-768.

Whiticar, M.J., Faber, E., and Schoell, M., 1986. Biogenic methane formation in marine and freshwater sediments: $\mathrm{CO}_{2}$ reduction vs. acetate fermentation-isotope evidence. Geochim. Cosmochim. Acta, 50:693-709.

Date of initial receipt: 3 October 1991

Date of acceptance: 26 February 1992

Ms 131SR-115 